\title{
NATAL NEST DISTRIBUTION AND PLEOMETROSIS IN THE DESERT LEAF-CUTTER ANT ACROMYRMEX VERSICOLOR (PERGANDE) (HYMENOPTERA: FORMICIDAE)
}

\author{
By Steven W. Rissing, * Robert A. Johnson,* \\ AND Gregory B. PollocK**
}

While most ant colonies are started by single queens, colony foundation by groups of queens, pleometrosis, also occurs (Wilson 1971, Hölldobler and Wilson 1977). Several extensively studied, highly pleometrotic species are notably similar with respect to important aspects of colony ontogeny and population dynamics. Myrmecocystus mimicus, Solenopsis invicta and Veromessor pergandei queens found colonies mutualistically without respect to relatedness (Bartz and Hölldobler 1982, Tschinkel and Howard 1983, Pollock and Rissing 1985, Rissing and Pollock 1986). Further, while adult colonies of these species are highly territorial (Hölldobler 1976a, 1981; Wilson et al. 1971; Went et al. 1972, Wheeler and Rissing 1975), natal colonies are clumped with brood raiding and subsequent worker defection from brood-raided colonies occurring (references cited above for $M$. mimicus and $S$. invicta, for $V$. pergandei: Rissing and Pollock, in press). Given such frequently deleterious natal colony interactions, adaptive value of habitat selection by founding queens resulting in clumping of natal nests is unclear. Natal nests of $M$. mimicus are generally clumped in areas devoid of adult nests (Bartz and Hölldobler 1982), yet still occur near such nests (B. Hölldobler, pers. comm.), and queens of $S$. invicta show some preference for microtopographic features (Tschinkel and Howard 1983). Here we present data relating habitat selection and clumping of natal nests of the highly pleometrotic leafcutter ant Acromyrmex versicolor (Pergande) directly to survival of founding queens. The only other report regarding any aspect of colony initiation in this species is a description of mating flights following summer rains in the Sonoran Desert by Wheeler (1917).

\footnotetext{
*Department of Zoology, Arizona State University, Tempe, AZ 85287

**School of Social Science; University of California, Irvine; Irvine, CA 92717 Manuscript received by the editor April 6, 1986.
} 


\section{MeThODS}

A major flight of $A$. versicolor occurred on 19 September 1985 on a study area in North Scottsdale, AZ $5.6 \mathrm{~km}$ north of Maricopa County along Pima Rd, approximately $3.2 \mathrm{~km}$ west of the McDowell Mountains. The habitat in this area is typical of the Sonoran Desert with Larrea tridentata and Franseria dumosa dominant shrubs and Olneya tesota and Cercidium microphyllum dominant trees along numerous shallow washes in the gravel/sandy soil. A major storm front produced rain throughout the region the previous day; $2.6 \mathrm{~cm}$ of rain was recorded at the Arizona State Laboratory of Climatology located $32 \mathrm{~km}$ south of the study area.

Habitat choice by $A$. versicolor queens was examined by running a transect $20 \mathrm{~m}$ long and $2 \mathrm{~m}$ wide from the base of 10 haphazardly chosen trees on the study area. Transect direction was chosen haphazardly. Distance of each starting nest from base of tree was recorded and standardized into "canopy units" by dividing by distance from base of tree to outer canopy edge along each transect. This standardization was necessitated by variance in tree size and canopy extent. Distance to nearest neighboring tree was measured for 20 haphazardly chosen trees and converted to canopy units using the larger canopy extent of each pair. Number of queens per starting nest was determined by excavating 43 nests during this time. Additionally, 21 starting nests were excavated on 22 September on a study area of similar habitat in South Mountain Park, Phoenix, $\mathrm{AZ}, 38.5 \mathrm{~km}$ southwest of the main study area.

Effect of temperature in a starting nest on queen survivorship was determined by placing 18 queens (from the above excavated nests) in a large test tube plugged with cotton and containing a large ball of cotton saturated with water to prevent desiccation. Test tubes were placed in a darkened incubator at $20,25, \ldots 45^{\circ} \mathrm{C}$ in random predetermined order; subsequently an additional tube was exposed to $42.5^{\circ} \mathrm{C}$. To mimic late afternoon temperature exposures in the field, tubes remained at their given temperature for 2 hours. Queens incapable of righting themselves after 2 hours were considered dead. Likely temperatures in starting nests were determined by taking soil temperatures 5 and $10 \mathrm{~cm}$ below surface at the trunk base ( 0 canopy units), canopy edge (1 canopy unit) and in the open ( $>1$ canopy unit) on the main study area between $16: 00$ and 17:00 $\mathrm{h}$ on 24 
September and 4 October 1985. All queens excavated 1-2 days following the mating flight were found $5-10 \mathrm{~cm}$ below the soil surface.

The possible importance of relatedness in formation of queen associations was tested according to the methods of Rissing and Pollock (1986). Eight plastic "choice boxes" $(30 \times 15 \times 8 \mathrm{~cm}$, half filled with sand moistened in each corner and at the midpoints along the long sides) were established with 2 sets of 4 queens, one set collected from each of the two study sites ( $38.5 \mathrm{~km}$ apart). In 5 boxes, queens were color marked according to collection locale; different patterns of the same two colors were used to avoid providing cues for recognition. As an additional control for possible paint odor, queens in the remaining 3 boxes were not marked. Boxes were excavated $24 \mathrm{hrs}$ later when queens had dug below the surface; location of each queen was noted relative to the others.

\section{RESULTS}

Acromyrmex versicolor queens strongly prefer to start nests immediately below the outer canopy of trees; while mean inter-tree distance was $6.10 \pm 1.85$ canopy units $(=21.37 \pm 5.14 \mathrm{~m}$ between tree bases; $\mathrm{N}=20$ ), the average starting nest was $.87 \pm .53$ canopy units $(=3.15 \pm 1.88 \mathrm{~m} ; \mathrm{N}=115)$ from a tree base (Fig. 1). Although measurements were not taken, the same distribution of starting nests was observed at South Mountain Park. All queens examined for temperature tolerance survived exposure to temperature up to and including $40^{\circ} \mathrm{C}$ for at least $2 \mathrm{hr}$; survivorship was 0 , however, at $42.5^{\circ} \mathrm{C}$ and above. Temperatures above $40^{\circ} \mathrm{C}$ were found in the open between trees ( $>1$ canopy units) at soil depths normally occupied by newly starting colonies $\left(\overline{\mathrm{x}}_{5 \mathrm{~cm}}=42.0( \pm 1.1)^{\circ} \mathrm{C}, \mathrm{N}=5\right.$; $\left.\mathrm{x}_{10 \mathrm{~cm}}=36.9( \pm 1.2)^{\circ} \mathrm{C}, \mathrm{N}=10\right)$; temperatures this high were not found at canopy edges ( $=1$ canopy unit $)\left(\mathrm{x}_{5 \mathrm{~cm}}=38.2( \pm 5.5)^{\circ} \mathrm{C}, \mathrm{N}\right.$ $\left.=5 ; \overline{\mathrm{x}}_{10 \mathrm{~cm}}=32.8( \pm 3.7)^{\circ} \mathrm{C}, \mathrm{N}=9\right)$ or at tree bases ( $=0$ canopy units) $\left.\left(\mathrm{x}_{5 \mathrm{~cm}}=28.91 \pm 2.4\right), \mathrm{N}=2 ; \overline{\mathrm{x}}_{10 \mathrm{~cm}}=27.4( \pm 0.8)^{\circ} \mathrm{C}, \mathrm{N}=5\right)$.

Acromyrmex versicolor is highly pleometrotic; $82.5 \%$ of all queens excavated $(\mathrm{N}=160$ queens from 64 nests) were from pleometrotic associations (Table 1). Relatedness appears unimportant in a queen's decision to enter a foundress association; five of the 8 "choice boxes" resulted in a single starting nest occupied by all 8 queens. The remaining 3 boxes had two starting nests each: of these 6 starting nests, 4 contained queens from both collection locales, 1 


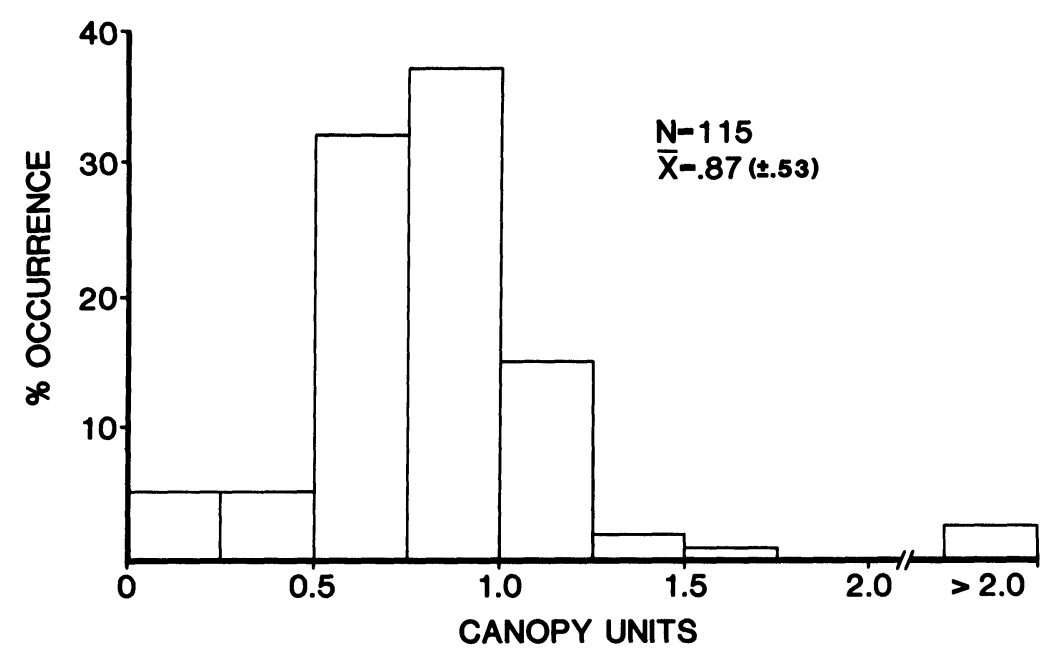

Figure 1. Habitat choice by Acromyrmex versicolor queens. "Canopy units" represent distance of a starting nest from the base of tree divided by distance from tree base to outer extent of canopy along that transect.

contained 3 queens from one site only, and the last contained a solitary foundress.

\section{Discussion}

The distinct habitat choice of $A$. versicolor queens (Fig. 1) seems a likely response to high soil temperatures in sunlit areas during the mid-late summer flight season of this species. Queens initiating nests in open areas will likely experience lethal temperatures even $5 \mathrm{~cm}$ below the soil surface. We routinely found queens at this depth 2-3 days following the mating flight. These nests, however, were located under trees where potentially lethal temperatures were never recorded. Acromyrmex versicolor queen death after 2 hours of exposure to temperatures $40-43^{\circ} \mathrm{C}$ is consistent with upper temperature tolerances of foragers of this species of $42-43^{\circ} \mathrm{C}$ (Gamboa 1976).

Queens of several other ant species display varying degrees of habitat choice. Queens of Lasius niger and Lasius flavus both prefer bare, sunlit soil where they establish colonies more successfully than 
Table 1. Pleometrosis in Acromyrmex versicolor.

\begin{tabular}{cc}
\hline No. queens in nest & Collection frequency \\
\hline 1 & 28 \\
2 & 16 \\
3 & 6 \\
4 & 7 \\
5 & 3 \\
7 & 2 \\
9 & 1 \\
16 & 1 \\
\hline
\end{tabular}

in shaded soil (Pontin 1960). Queens of the tropical leaf-cutting ant Atta cephalotes appear capable of choosing between major habitat types (mature evergreen woodlands as opposed to deciduous forest or cultivated fields) (Rockwood 1973). Similar ability to choose between major habitat types (woods versus open fields) while flying occurs in Lasius neoniger and Solenopsis molesta (Wilson and Hunt 1966).

Preference by queens for the canopy edge (as opposed to anywhere under a tree) may represent a trade-off for shade while still being as warm as possible for rapid development of an initial worker force and eventual establishment of a foraging territory. This would be consistent with the high degree of pleometrosis in this species (see below) and with the "maxi-therm" hypothesis of Hamilton (1973). Location of a starting nest under a tree canopy (especially $O$. tesota whose branches frequently droop to the ground) would permit easy and safe access to vegetation for initiation and growth of the fungus garden characteristic of all leaf-cutters. Unlike most species of higher ants, queens of Acromyrmex spp., including $A$. versicolor, routinely forage for vegetation, especially at colony initiation (Weber 1972, Gamboa 1974). Trees, including $O$. tesota, are commonly harvested by $A$. versicolor (Gamboa 1975).

Of the several hundred adult colonies of $A$. versicolor we have observed within the vicinity of Phoenix, AZ, virtually all have been located directly under adult trees and never in the open between trees. Acromyrmex, Atta and related genera are a largely tropical, New World group of ants; $A$. versicolor is the northernmost of 24 Acromyrmex species and certainly one of the most desert-adapted of all the leaf-cutters (Creighton 1950, Weber 1972). Habitat choice by founding queens and location of adult nests under trees may be 
an important behavioral adaptation permitting range extension into the Sonoran Desert. Acromyrmex versicolor queens clump around the essential resource of favorable nest sites (tree shade with ready access to lower canopy leaves). The mating system of this species may also permit "tracking" of this resource. Unlike some desert species that have massive mating swarms (e.g. Pogonomyrmex spp.: Chapman 1957; Nagel and Rettenmeyer 1973; Hölldobler 1976b, c; Davidson 1982), A. versicolor mates in small, localized groups at or near the ground in open areas between trees (Wheeler 1917; R. A. Johnson, pers. obs.). This behavior mimics closely the mating behavior of $M$. mimicus (M. Cazier, pers. comm.) and likely $V$. pergandei (Pollock and Rissing 1985), pleometrotic species with clumped natal nests. Whether such localized mating aggregations have led to a highly female biased sex ratio, as appears to have occurred in $V$. pergandei (Pollock and Rissing 1985), is currently unknown for these other pleometrotic species.

Some other ant species with clumped, natal nests engage in internest brood raiding in the process of establishing natal territories (references cited above). This may select for pleometrosis (Rissing and Pollock, in press) which generally results in more rapid production of a larger initial worker force (Waloff 1957; Stumper 1962; Markin et al. 1972; Taki 1976; Mintzer 1979; Bartz and Hölldobler 1982, Tschinkel and Howard 1983, Rissing and Pollock, in press). Colonies of these species are also territorial as adults. Brood raiding also seems likely in Atta texana, another pleometrotic desert leafcutter (Mintzer and Vinson 1985), which "merges" young colonies in the laboratory and field (Echols 1966). Adult colonies of Acromyrmex versicolor are territorial (Gamboa 1974). We suggest such territoriality, when coupled with natal nest clumping through habitat choice, makes brood raiding and associated forms of natal nest competition likely for this species as well.

A final similarity between $A$. versicolor and other pleometrotic ants with clumped natal nests discussed here is the apparent formation of foundress associations without respect to relatedness. Queens collected from distant locales readily associate. Similar observations exist for M. mimicus (Bartz and Hölldobler 1982), $A$. texana (Mintzer and Vinson 1985) and $V$. pergandei (Rissing and Pollock 1986); electrophoretic evidence indicates $S$. invicta queens also associate randomly (Ross and Fletcher 1985). This differs 
dramatically from the close relatedness of cofoundresses in primitively eusocial wasps (Pfennig et al. 1983 and included references). Given the normally claustral method of colony foundation in ants, relatedness to potential cofoundresses should be unimportant in this essentially mutualistic process (Rissing and Pollock 1986). Colony foundation in leaf-cutters (including $A$. versicolor), however, is not claustral; foundresses forage (references cited above). This presents an opportunity to extend and examine the dynamics of the mutualistic process of colony foundation by unrelated females. Work in this area is currently planned.

\section{SUMMARY}

Queens of the desert leaf-cutter ant, Acromyrmex versicolor exhibit distinct habitat choice during colony foundation; almost all natal nests are located directly under the canopy edge of large trees. Soil temperatures in these sites are conducive to queen survivorship during the first several days of colony initiation while those in open areas between trees are high enough to result in queen death. This habitat choice results in clumping of many natal nests under individual trees implying strong natal colony competition. Indeed, as with several other ant species exhibiting such competition, starting colonies are frequently pleometrotic; $82.5 \%$ of all queens excavated were from such multiple foundress associations. As with other pleometrotic ant species, mating aggregations of $A$. versicolor are small and localized, and relatedness appears unimportant in a queen's decision to enter a foundress association.

\section{ACKNOWLEDGMENTS}

G. E. Walsberg provided advice regarding queen temperature tolerance tests.

\section{Literature Cited}

BARTZ, S. H. AND B. HÖLLDOBLER

1982. Colony founding in Myrmecocystus mimicus Wheeler (Hymenoptera: Formicidae) and the evolution of foundress associations. Behav. Ecol. Sociobiol. 10: 137-147.

Chapman, J. A.

1957. A further consideration of summit ant swarms. Canadian Entomol. 89: 389-395. 
Creighton, W. S.

1950. The ants of North America. Bull. Mus. Comp. Zool. 104: 1-585.

Davidson, D. W.

1982. Sexual selection in harvester ants (Hymenoptera: Formicidae: Pogonomyrmex). Behav. Ecol. Sociobiol. 10: 245-250.

Echols, H. P.

1966. Compatibility of separate nests of Texas leaf-cutting ants. J. Econ. Ent. 59: $1299-1300$.

GAMBOA, G. J.

1974. Surface behavior of the leaf-cutter ant Acromyrmex versicolor versicolor Pergande (Hymenoptera: Formicidae). Masters Thesis; Arizona St. Univ., Tempe, Arizona.

1975. Foraging and leaf-cutting of the desert gardening ant Acromyrmex versicolor versicolor (Pergande) (Hymenoptera: Formicidae). Oecologia (Berl.) 20: 103-110.

1976. Effects of temperature on the surface activity of the desert leaf-cutter ant, Acromyrmex versicolor versicolor (Pergande) (Hymenoptera: Formicidae). Amer. Midl. Natur. 95: 485-491.

HamiLton, W. J.

1973. Life's Color Code. McGraw-Hill, New York, N.Y.

HÖLLDOBLER, $B$.

1976a. Tournaments and slavery in a desert ant. Science 192: 912-914.

1976b. The behavioral ecology of mating in harvester ants (Hymenoptera: Formicidae: Pogonomyrmex). Behav. Ecol. Sociobiol. 1: 405-423.

1976c. Recruitment behavior, home range orientation and territoriality in harvester ants, Pogonomyrmex. Behav. Ecol. Sociobiol. 1: 3-44.

1981. Foraging and spatiotemporal territories in the honey ant Mrymecocystus mimicus Wheeler (Hymenoptera: Formicidae). Behav. Ecol. Sociobiol. 9: 301-314.

HÖLLDOBLER, B. AND E. O. WiLSON.

1977. The number of queens: An important trait in ant evolution. Naturwissenschaften 64: 8-15.

Markin, G. P., H. L. Collins, and J. H. Dillier.

1972. Colony founding by queens of the red imported fire ant, Solenopsis invicta. Ann. Entomol. Soc. Am. 65: 123-124.

MinTZer, A.

1979. Colony founding and pleometrosis in Camponotus (Hymenoptera: Formicidae). Pan-Pacific Entomol. 55: 81-89.

Mintzer, A. AND S. B. Vinson.

1985. Cooperative colony foundation by females of the leafcutting ant Atta texana in the laboratory. J. New York Entomol. Soc. 93: 1047-1051.

NAGel, H. G. AND C. W. ReTtenMEYer.

1973. Nuptial flights, reproductive behavior and colony founding of the western harvester ant, Pogonomrymex occidentalis (Hymenoptera: Formicidae). J. Kansas Entomol. Soc. 45: 82-101.

Pfennig, D. D., G. J. Gamboa, H. K. Reeve, J. S. Reeve, and I. D. Ferguson.

1983. The mechanism of nestmate discrimination in social wasps (Polistes, Hymenoptera: Vespidae). Behav. Ecol. Sociobiol. 13: 299-305. 
Pollock, G. B. AND S. W. Rissing.

1985. Mating season and colony foundation of the seed-harvester ant, Veromessor pergandei. Psych 92: 125-134.

Pontin, A. J.

1960. Field experiments on colony foundation by Lasius niger (L.) and $L$. flavus (F.) (Hym., Formicidae). Ins. Soc. 7: 227-230.

Rissing, S. W. AND G. B. Pollock.

1986. Social interaction among pleometrotic queens of Veromessor pergandei (Hymenoptera: Formicidae) during colony foundation. Anim. Behav., 34: 226-233.

Queen agression, pleometrotic advantage and brood raiding in the ant Veromessor pergandei (Hymenoptera: Formicidae). Anim. Behav., in press.

Rockwood, L. L.

1973. Distribution, density and dispersion of two species of Atta (Hymenoptera: Formicidae) in Guanacaste Province, Costa Rica. J. Anim. Ecol. 42: 803-817.

Ross, K. G. ANd D. J. C. Fletcher.

1985. Comparative study of genetic and social structure in two forms of the fire ant Solenopsis invicta (Hymenoptera: Formicidae). Behav. Ecol. Sociobiol. 17: 349-356.

STUMPER, R.

1962. Sur un effet de groupe chez les femelles de Camponotus vagus (Scopoli). Ins. Soc. 9: 329-333.

TAKI, A.

1976. Colony founding of Messor aciculatum (Fr. Smith) (Hymenoptera: Formicidae) by single and grouped queens. Physiol. Ecol. Japan 17: 503-512.

TSChinkel, W. R. AND D. F. Howard.

1983. Colony founding by pleometrosis in the fire ant, Solenopsis invicta. Behav. Ecol. Sociobiol. 12: 103-113.

WALOFF, N.

1957. The effect of the number of queens of the ant Lasius flavus (Fab.) (Hym., Formicidae) on their survival and on the rate of development of the first brood. Ins. Soc. 4: 391-408.

WEBER, N. A.

1972. Gardening ants the Attines. Mem. Amer. Phil. Soc. 92: 1-146.

Went, F. W., G. C. WheEler, AND J. WheELER.

1972. Feeding and digestion in some ants (Veromessor and Manica). Bioscience 22: 82-88.

WHEELER, J. AND S. W. RISSING.

1975. Natural history of Veromessor pergandei. II. Behavior. Pan-Pacific Entomol. 51: 303-314.

WHEELER, W. M.

1917. Notes on the marriage flights of some Sonoran ants. Psyche 24: 177-180.

WILSON, E. O.

1971. The Insect Societies. Cambridge, Massachusetts: Belknap Press of Harvard University Press. 
Wilson, E. O. AND G. L. Hunt.

1966. Habitat selection by the queens of two field-dwelling species of ant. Ecology 47: 485-487.

Wilson, N. L., J. H. Dillier, AND G. P. Markin.

1971. Foraging territories of imported fire ants. Ann. Entomol. Soc. Amer. 64: 660-665. 

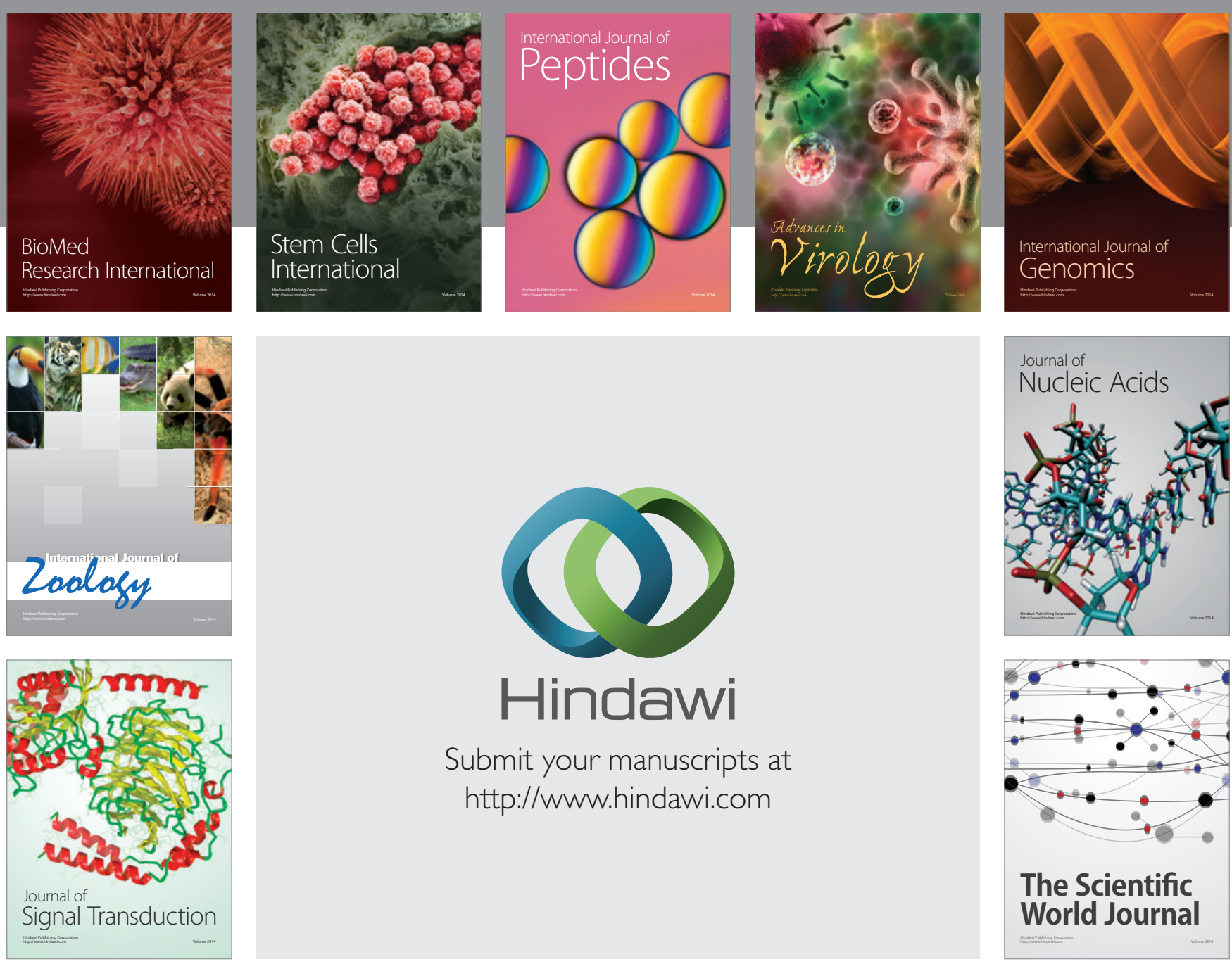

Submit your manuscripts at

http://www.hindawi.com
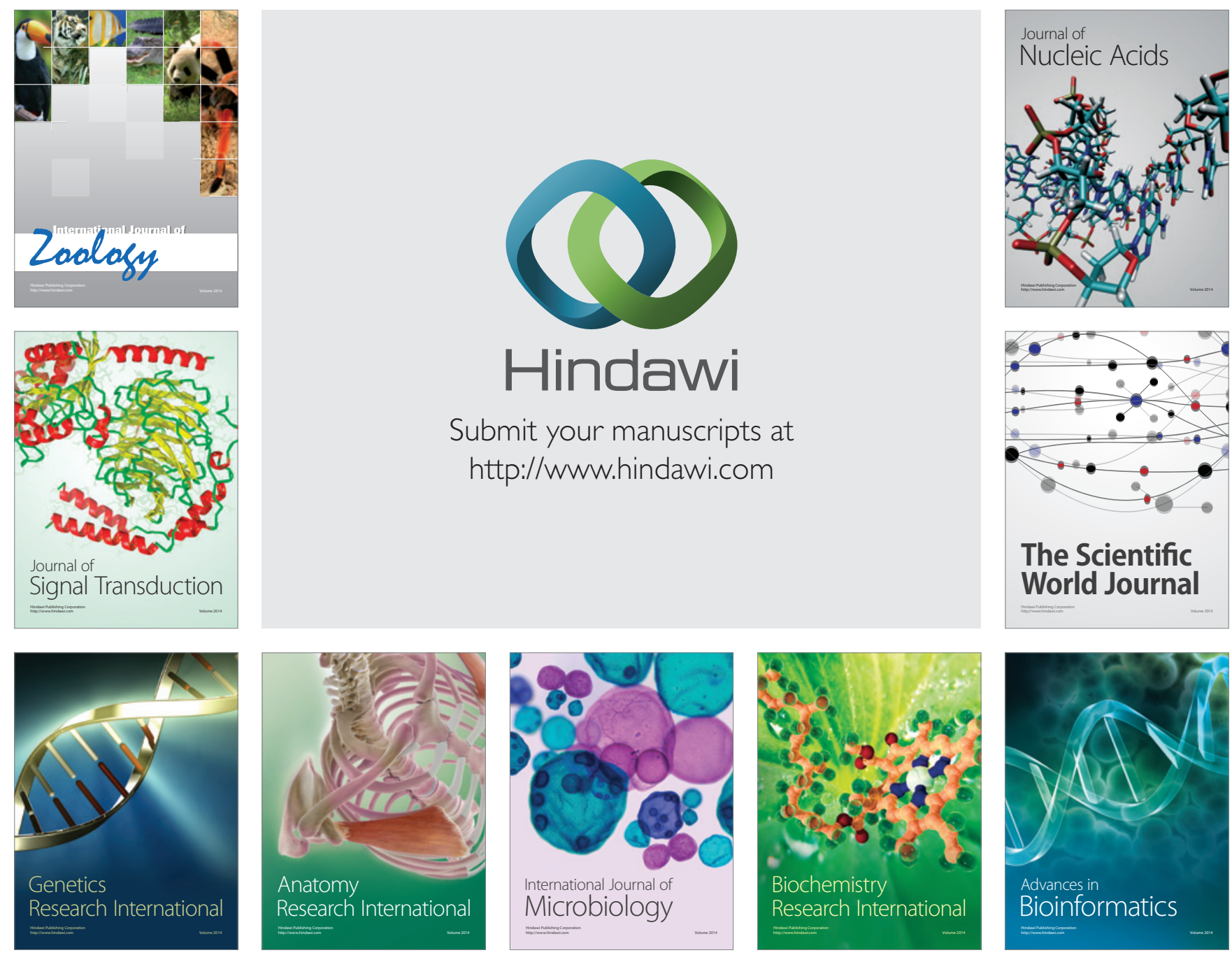

The Scientific World Journal
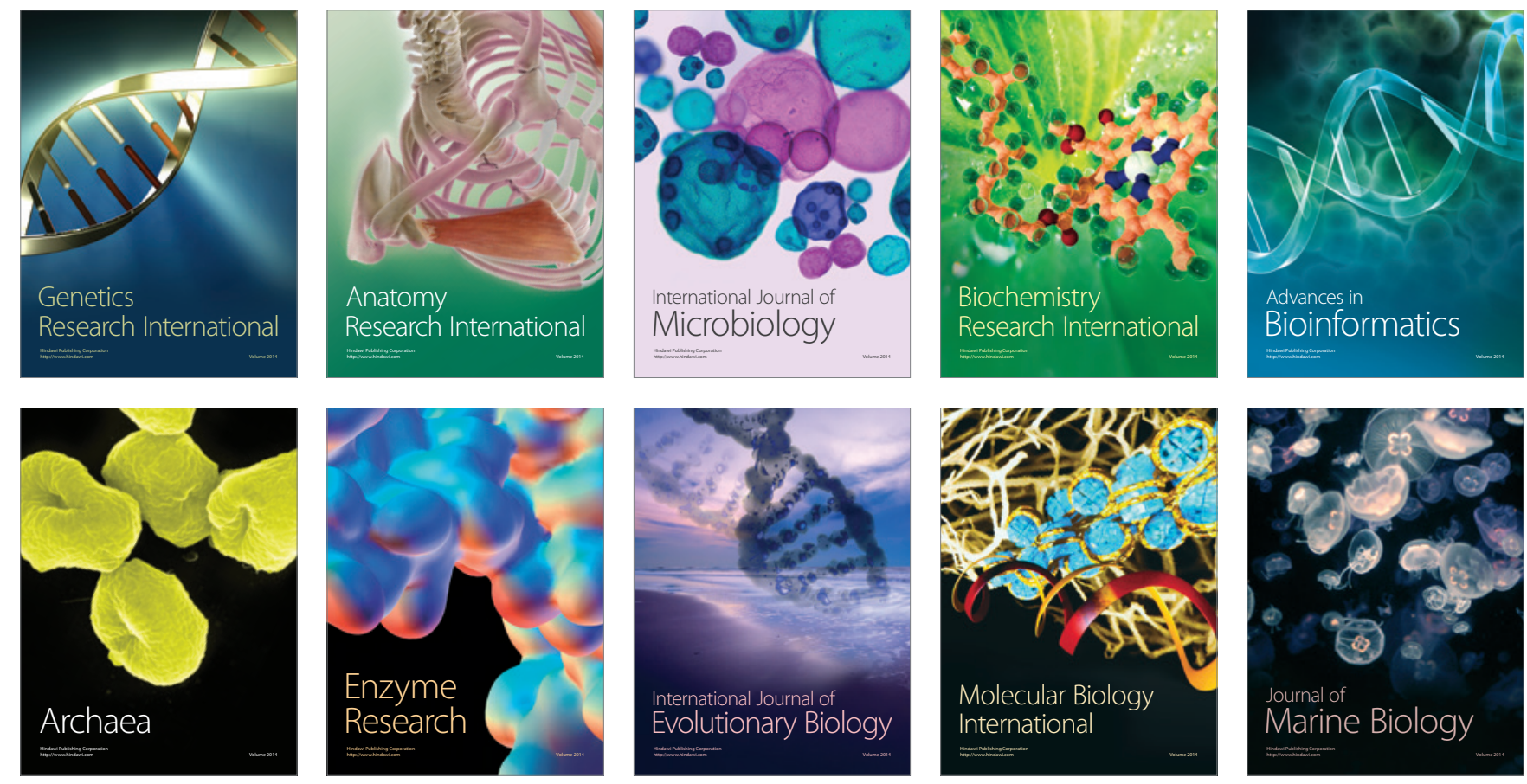